FILM CRITICISM IN THE DIGITAL AGE 



\section{FILM CRITICISM IN THE DIGITAL AGE}

EDITED BY

MATTIAS FREY AND CECILIA SAYAD

RUTGERS UNIVERSITY PRESS

New Brunswick, New Jersey and London 
Library of Congress Cataloging-in-Publication Data

Film criticism in the digital age / edited by Mattias Frey and Cecilia Sayad.

pages $\mathrm{cm}$

Includes bibliographical references and index.

ISBN 978-0-8135-7073-0 (hardcover : alk. paper) — ISBN 978-o-8135-7072-3

(pbk. : alk. paper) — ISBN 978-o-8135-7074-7 (e-book (web pdf)) -

ISBN 978-0-8135-7364-9 (e-book (epub))

1. Film criticism. 2. Motion pictures-Philosophy. 3. Mass media-Technological innovations. I. Frey, Mattias, editor. II. Sayad, Cecilia, editor.

PN1995.F4573 2015

$791.4301-\mathrm{dc} 23$

2014030640

A British Cataloging-in-Publication record for this book is available from the British Library.

This collection copyright (C) 2015 by Rutgers, The State University Individual chapters copyright $(C 2015$ in the names of their authors All rights reserved

No part of this book may be reproduced or utilized in any form or by any means, electronic or mechanical, or by any information storage and retrieval system, without written permission from the publisher. Please contact Rutgers University Press, 106 Somerset Street, New Brunswick, NJ 08901. The only exception to this prohibition is "fair use" as defined by U.S. copyright law.

Visit our website: http://rutgerspress.rutgers.edu

Manufactured in the United States of America 